\title{
International Experience of Pension Funds' Infrastructure Investment and Its Enlightenment to China
}

\author{
Ruan Xiang* \\ School of Public Finance And Management \\ Yunnan University of Finance and Economics \\ Kunming, China \\ xxrfrxx@163.com
}

\begin{abstract}
Having been through the financial crisis, each country has seen seeking new and more secure investment areas for pension funds and has attracted much attention on the investment of infrastructure. On the basis of the income and expenditure pressure of pension funds and the requirement of infrastructure construction, it is even more necessary for China to invest the infrastructure in its pension funds. The experience of infrastructure investment in Canada, Australia, Latin America and other countries has provided valuable inspiration for Chinese pension fund practice.
\end{abstract}

Keywords-Pension Funds ; Infrastructure Investment ; Investment Model ; Risk-prevention

\section{INTRODUCTION}

Having experiencing the huge losses caused by the financial crisis in 2008, countries have begun to review the investment tools and investment strategies of pension funds. On the one hand, pension funds urgently need to seek new investment directions to disperse their investment portfolios and ensure the safety and profitability of investments. On the other hand, pension funds expect to find certain assets to better match their structure of assets and liabilities. Infrastructure investment, on the basis of its low relevance to financial markets, long-term investment, and excellent risk-reward, can exactly meet the investment needs of pension funds. Moreover, infrastructure construction is crucial to the development of a country's society and economy. The funding gap of global infrastructure is huge, so it is urgent to develop and extend new financing channels and methods. Therefore, investing infrastructure by using pension funds can create a "win-win" situation for both parties. On the basis of the 2013 OECD survey, 35 large-scale pension funds have invested US\$80 billion in infrastructure construction projects, accounting for $3.4 \%$ of total assets. The proportion of infrastructure assets in the pension fund portfolio ranges from $0 \%$ to $31 \%$. Such assets in the countries such as Canada and Australia have achieved more than $10 \%$ of the pension fund's good investment performance.

Since the 1990s, foreign scholars have made an extensive research on the investment of pension funds on infrastructure. Georg Inderst $(2008,2009)$ has conducted a comprehensive analysis of the investment of pension fund on infrastructure, including the analysis on choice of investment methods, the risk returns of investment, the selection of evaluation criteria, and supervision. It was considered that the use of private equity funds for infrastructure investment is a feasible choice for pension fund. On account of empirical data. ${ }^{[1]}$ Asieh Mansour (2007) made an analysis on the risk-return characteristics and its investment performance of different types of infrastructure projects. ${ }^{[2]}$ Domestic scholars' research on the investment of Pension fund on infrastructure mainly focuses on the qualitative analysis of the feasibility and implementation path of the investment. However, the investment in infrastructure projects is complicated, which has specific risks in financing, construction, operations, and supervision. What's more, owing to the differences in national conditions and other conditions, it requires Chinese pension funds and policy makers have a more cautious attitude when drawing on the successful experience of other countries. The significance of international comparative research is further highlighted. In recent years, domestic scholars have carried out international comparative studies in this area, including Yuan Zhongmei's study (2016) on Australia and Canada, Tian Tianyuan's study (2014) on Latin American countries, and Shen Yuzheng's study (2013) on Canada. On the basis of absorbing the above-mentioned research results, this paper starts with the analysis of the necessity and feasibility of China's investment of pension fund on infrastructure construction so as to propose countermeasures and suggestions for promoting China's investment of pension fund on infrastructure construction.

\section{BODY}

\section{A. China's Investment of Pension Fund on Infrastructure}

\section{Construction is just in Time}

1) High Matching of Properties and Characteristics of Infrastructure Investment and Pension Funds

Firstly, there is a high requirement for initial input requirements, with a long cycle and a stable cash flow. In general, the scale of infrastructure construction is large, so the initial investment must reach a certain level in order to ensure 
the smooth construction of the projects. Moreover, due to the long duration, investors are required to have a long-term and stable financial support. With accumulation becoming the direction and goal of pension system reform in various countries, it will inevitably lead to the substantial accumulation of funds. According to the mandatory characteristics of the pension insurance system, the duration will be as long as 20 to 30 years or even longer, which can meet the needs of infrastructure investment for a long-term and stable fund.

Secondly, the income is relatively stable. Usually, the industrial life of the infrastructure is long and the operating costs are relatively low, so it is possible for infrastructure industry to obtain relatively stable returns. Moreover, owing to the inherent characteristics of the infrastructure, it can do a good job in resisting the inflation and economic fluctuations on the erosion of asset value, and effectively realize the preservation and appreciation of investment. These features are in line with the pension fund's pursuit of the best combination of investment security and profitability.

Thirdly, the correlation with other assets is low. In accordance with the Markowitz's portfolio theory, the smaller the correlation coefficient among various types of assets, the stronger the ability of the portfolio to spread risk. In order to better prevent investment risks of pension funds, it is necessary to decentralize investment. While the correlation between infrastructure investment and traditional investment area is relatively low, it is insensitive to fluctuations in the economy, interest rates and stock markets, which is conducive to better diversification of investment risk and guarantee the safety of the fund.

\section{2) The Pressure of Chinese Pension Funds to Preserve Value and Add Value}

Since the reform and opening up, China has initially established a pension insurance system covering both urban and rural areas. Up to the end of 2016, China has covered 888 million people in its basic pension insurance system and its accumulated balance had reached 4.396 trillion Yuan. However, due to the low level of co-ordination fund and the immature domestic capital market, China only allow to use basic endowment insurance funds to purchase treasury bonds or deposit in bank accounts for a long time. In recent years, with the increasing aging of the population and the growth rate of fund income is slowing down, expenditures are growing in a rapid rate, the pressure on revenue and expenditure will increase year by year, and the financial sustainability of pension insurance funds will face a severe challenge. Up to now, some areas have already met the situation that pension funds live beyond its income and run out of balance. Therefore, as for the sustainable development of China's pension insurance system, it is quite important to improve and perfect the operational system of pension insurance fund investment and realize the preservation and appreciation of the fund as soon as possible. The issuance of the Investment Management Regulations for Basic Pension Insurance Fund in August 2015 marked the formal transition of China's basic pension investment management to marketization, diversification, and specialization. At the same time, the establishment of the National Social Security Fund in 2000 has accumulated a lot of experience for China's pension fund investment. By the end of 2016, due to a diversified market investment strategy, the investment scope of the fund has been continuously expanding, with an average annual investment yield of $8.37 \%$. Therefore, the main source of funds has been changed from fiscal allocation to the income generated from continuous investment operation, which has greatly achieved the preservation and appreciation of funds. In terms of infrastructure investment, the National Social Security Fund has also taken active actions in transportation, energy, water conservancy, and other projects, which has made infrastructure become a promising investment field.

\section{3) China's Requirement in Infrastructure Financing and the "One Belt One Road" Strategy}

Investment has long been regarded as China's most important tool in economic growth. In particular, investment in infrastructure construction can not only bring the economic growth in the investment itself, but the continuous improvement of infrastructure will also produce a multiplier effect. However, China's current infrastructure investment directly reflects insufficient effective investment and shortage of construction funds. The research report issued by the McKinsey Company in its Urban China Initiative in 2013 pointed out that China will need approximately 300,000 to 3, 000 billion Yuan in its infrastructure construction by 2020 . Apart from the financial investment, there will be a financing gap about 100 to 200 billion Yuan that needs to be filled by other social funds. The involvement of pension funds can meet the China's huge demand fund in infrastructure investment, and infrastructure investment during the rising period is also a good opportunity for pension funds to preserve their values and add their values.

Apart from China, at present and for a period of time in the future, the demands for global infrastructure construction and capital financing are both strong. According to the research of McKinsey Company, the investment demand of global infrastructure during 2015-2030 is US\$87 trillion. In particular, infrastructure construction is generally weak in some developing countries and emerging economies, so it has a strong demand for infrastructure construction. In recent years, Chinese companies have greatly participated in the construction of overseas infrastructure projects, and the scale of investment has continued to expand. In particular, China has greatly expanded its direct investment in countries that related to the "One Belt One Road". Investing pension funds in some overseas infrastructure projects can not only obtain investment income, but also make contribution to the "One Belt One Road" strategy. It will use infrastructure investment as a bridge to open up the three-dimensional energy transportation of shipping, railways, highways and pipelines, enhance regional economic cooperation and mutual political trust, and expand multilateral economic and trade cooperation.

\section{B. International Experience of the Investment of Pension}

\section{Fund on Infrastructure}

\section{1) Investment Methods}

\section{a) Indirect Investment}

Foreign pension funds often start with indirect investment methods in their infrastructure investment. Only when they accumulate some experience or wait until the pension fund reaches a certain scale will they make a direct investment. Tools for indirect investment include stocks, bonds and private equity funds. As for the four countries in Latin 
America, Chile, Peru, Mexico, and Colombia, the amount of pension fund indirect investment in infrastructure accounts for $86 \%, 73 \%, 76 \%$, and $100 \%$ of the total pension fund in infrastructure investment. ${ }^{[3]}$

In November 2010, a total of $\$ 7.508$ billion of pension funds in Chilean pension funds invested in infrastructure stocks, which accounted for $33 \%$ of the fund equity assets. In terms of bond investment, a total of $4.8 \%$ of pension funds invest in infrastructure through bonds, which account for $13.8 \%$ of the total assets of domestic fixed income securities. ${ }^{[4]}$ Usually, on account of the high leverage ratio of infrastructure construction projects, the proportion of equity financing is often small, and the target of debt financing is mainly bank loans. Therefore, the more common indirect investment method is indirect investment through professional private equity funds. . Most of Australian infrastructure investments of the pension funds are outsourced to external fund managers. Owing to the low investment cost, most Australian pension funds are decided to invest in unlisted open infrastructure funds. Eight of the top 20 infrastructure fund managers in the world are from Australia and most of them operate funds in the whole world. For example, the Queensland Investment Company, which was formally established in 1991, is an open-end fund owned by the Queensland Government. It is also an active investor in long-term infrastructure assets. It has established an infrastructure team in 2006, which has become the choice of infrastructure investment for many small-scale superannuity funds investment. ${ }^{[5]}$

\section{b) Direct Investment}

In the case of direct investment, the pension funds has ownership and certain control over the infrastructure, but it has a higher requirement for the management ability of the pension fund and requires the internal staff of the pension fund to be familiar with the project's knowledge of bidding, construction, management and assets disposal. Therefore, the ability to adopt this type of investment for pension funds is not much. Most of the infrastructure investment for Canadian pension funds is direct investments. These pension funds already have extensive experience in infrastructure investment and have established or are establishing their own expert teams. Because of the higher transaction costs and the large amount of investment, pension funds through directly investment usually adopts the mode of joint investment. For instance, GSIA, the global joint investment platform launched by OMERS in 2012, was originally designed to gather like-minded investors (mainly pension funds) for direct investment in infrastructure assets in March 2014. OMERS and the world's largest pension funds - the Japanese Government Pension Fund (GPIF) and the Development Bank of Japan (DBJ) signed an agreement on joint investment, making the total capital of GSIA increased to 11.25 billion US dollars. ${ }^{[6]}$

\section{2) The Innovation of Investment Instruments}

In order to promote the pension fund's investment in infrastructure and ensure the safety of the pension fund, all countries, in addition to traditional investment tools, have explored new investment tools that are in line with pension fund investment preferences. In 1998, Chile created Infrastructure Bond issued by companies that obtained franchise rights to finance projects. Infrastructure bonds do not have early redemption rights and are mostly guaranteed by international insurance companies. Therefore, the rating of issuance at that time is higher.

While Mexico has created a new hybrid capital/debt security called Capital Development Certificates, abbreviated as CKDs, which is a type of trust certificate designed to support the finance of infrastructure projects and real estate projects through the placement between institutional investors. It also has the characteristics of debt investment instruments and equity investment instruments. The holders cannot collect principal and interest on time, but can obtain "dividends" based on investment returns, and it has an Amortization Date and may be repaid in advance.

In 2009, in order to alleviate the impact of the financial crisis on the Peruvian economy and expand infrastructure investment, led by the Peruvian government, the government, multilateral organizations (mainly $\mathrm{CAF}$ and $\mathrm{IADB}$ ) and Peruvian pension fund finance together to establish infrastructure investment funds. The same year, the Peruvian pensions association has created an infrastructure investment trust fund. Trust funds invest primarily through debt instruments and are held-to-maturity investments. The trust fund's investment committee consists of representatives from four pension funds, which guarantees the control of pension fund over the entire investment process. In addition, there are investment consultants in the trust fund who have rich experience in investment investigations and analysis of infrastructure projects. They are responsible for helping determine investment objectives, setting up investment strategies, standardizing the investment process, and provide advisory negotiations and related work. This will help resolve the delays and the problems related to franchise contracts that may be faced by the direct investment infrastructure of individual pension fund as well as the lack of external investment advice. ${ }^{[7]}$

\section{3) Investment Ratio}

On the whole, although the proportion of pension funds investing in infrastructure has continued to grow from scratch, the overall investment scale remains quite small. There are still large differences in the scale of infrastructure investment in various countries. The Canada and Australia, as leaders in this field, separately started their pension fund in 21st century and the 1990s. At present, their investment ratios are $6.6 \%$ and $8.6 \%$ respectively, far exceeding the global average level of $1 \% .{ }^{[8]}$ In accordance with the PIAC statistics, the average allocation ratio of large-scale pension funds in Canada is more than $5 \%$, with OMERS in $19.97 \%$, followed by OTPP $8.19 \%$, PSPP $6.79 \%$ and CPPIB $5.74 \%$. Owing to the strong internal management capabilities of these large-scale pension funds, they have independent professional investment committees, understanding complex direct investment projects, effectively making investment assessments and investment decisions for infrastructure projects so as to make their investment in infrastructure continuously increasing. ${ }^{[9]}$ Statistics from the Australian Prudential Regulation Authority (APPA) show that as of June 2015, the asset ratio of infrastructure assets in the whole superannuity industry was $4 \%$, of which, the industry fund investment ratio was up to $8 \%$, followed by My Super in 7\%. The lowest proportion of retail fund investment is only $1 \% .^{[10]}$ Apart from the two countries mentioned above, the proportion of pension fund investment infrastructure in other countries is still small, of which, the European continent is only $2 \%$. Therefore, it needs to make an improvement in the future. 


\section{4) Investment Income}

An OECD survey shows that the annual expected return on investment infrastructure over the past 10 years is $9.5 \%$, second only to private equity investment $(11.3 \%)$, higher than the investment of stocks $(9.0 \%)$ and bonds $(5.1 \%)$. However, the income from investment infrastructure is not stable. When the construction of global infrastructure is in a period of high growth, the annual expected rate of return can reach more than $15 \%$. The return rate of expected total investment for a mature project is $10 \%$ to $14 \%$ per year, and while the return rate of project construction period is over $18 \%$. Nevertheless, when economic downturns hit, the expected return on the investment infrastructure will fall below $10 \%$. ${ }^{[11]}$ The geometric mean of infrastructure investment in Canada between 2006 and 2014 ranged from $7.2 \%$ to $11.8 \%$, much higher than the inflation rate over the corresponding period. As the oldest pension funds with the earliest time and the largest proportion of investment in infrastructure investment, OMERS is also the one with the minimum investment rate of return and volatility. The reason is that it has established a wholly-owned subsidiary Borealis infrastructure since 1999, and has invested extensively in infrastructure projects for Canada, the United States, the United Kingdom, the European Union, etc., by obtaining ownership of not less than $25 \%$ to expressed its opinions and opinions actively for all matters related to assets and business. Peng and Newell (2007) compared the performance of risk adjustment for Australia's listed and unlisted infrastructure companies and funds in the first decade of 2006. From the perspective of average annual rate of return, the rate of return on listed infrastructure investment was $22.4 \%$, compared with $14.1 \%$ for non-listed companies, both of which beat the bond yield $(7.2 \%)$ and stock yield (12.9\%) in the same period. ${ }^{[12]}$ Moreover, Russell Investments (2012) summarizes the yields of Australian non-listed infrastructure funds over the past 15 years. For the total revenue of average annual including fees and taxes, the long-term (12\% for 15 years), medium-term (7 years) and short-term (13\% for 1 year) yields performed well, and the growth rate of average annual assets increased with the extension of the term. ${ }^{[13]}$ In general, despite the volatility, the investment of Pension fund on infrastructure has achieved reliable average returns over the long term in a mature institutional framework.

\section{The Enlightenment to China}

\section{1) Gradually Reduce the Investment Restrictions of Pension Fund}

The main obstacle for pension funds to invest in infrastructure is the constraints imposed by the government's investment management measures, such as restricting its overseas investment, private equity investment, real estate investment, or other alternative asset investment, as well as restrictions on controlling shares, single object investment ratios and credit rating in in listed company stocks and bonds. With the promulgation of the Investment Management Regulations on Basic Endowment Insurance Fund and the various investment attempts that have been implemented by the National Social Security Fund, China should appropriately relax the scope and types of pension funds' investment and expand its infrastructure, green environmental protection, and low-carbon technologies and other emerging sectors in the field of investment channels. It should especially to increase infrastructure structured products and private equity investment funds, while eliminating unnecessary or excessive quantitative investment restrictions, and gradually shifting to a supervision model conducted by prudent persons, so that the value of funds can be maintained while adding value, and actively support infrastructure construction in China and related countries.

\section{2) Regulate and Improve the Infrastructure Market}

First, the government should accelerate the reform of its investment system, actively promote the PPP model, and attract social capital investment in various ways. Second, establish the market mechanism for infrastructure finance, enforce the system of public information in project investment and vigorously support independent data collection and objective information provision for infrastructure investment both at home and abroad. Third, endeavor to explore the standard risk assessment system and the sustainable assessment system of project financial for infrastructure investment. Innovate the dynamic assessment methods for infrastructure project risks and benefits, and establish an authoritative infrastructure investment index. Fourth, improve laws and regulations such as franchising, so that all investments can be smoothly carried out based on the protection of the legal system.

\section{3) From Indirect Investment to Direct Investment}

However, because China's pension fund has just started its investment in infrastructure, so that it is difficult to establish a professional investment team due to its lack of relevant investment experience, although the scale of funds will increase. Therefore, the enterprise annuity of China's pension funds investing in the infrastructure sector can start with the securities market and gradually develop into investment in investment trusts. By entrusting investment and operation of pension funds in infrastructure to third parties directly, this can take advantage of a huge leverage, by obtaining greater benefits at a smaller cost. When pension funds have accumulated certain experience in infrastructure investment, China's pension fund also reached a certain level. In the meanwhile, China's infrastructure market has also matured, and there are many experts on infrastructure investment in the market. Furthermore, China's pension funds can also gradually try to invest directly in infrastructure, especially for overseas infrastructure, so as to obtain higher risk adjusted returns.

\section{4) Strengthen Financial Innovation}

In order to better promote the investment of pension fund for infrastructure, China should increase the financial innovation of investment infrastructure of pension fund. First, China can also set up an infrastructure investment bank or investment fund by the government, and flexibly use equity, debt, and other investment methods for pension funds so as to create a reliable and profitable investment channel of infrastructure projects. Second, under the premise of without affecting the supervision of pension funds on the safety of pension fund investment, infrastructure bonds can be issued to attract pension funds to invest. The payment of principal and interest of infrastructure bonds issued by the cash flow generated during the operation of the project can seek full or partial financial guarantees for international professional insurance company. Third, by increasing the investment options for pension funds in the form of listed structured products or private equity funds, China's securities market is 
more mature and it draw lessons from the Mexican structured investment vehicles CKDs.

\section{5) Risk Control}

For pension funds, the conventional risks faced by the investment financial market are relatively easy to control. However, for the specific risks of investment in infrastructure projects, it is necessary to establish a professional team for its own infrastructure investment, and necessary for the involvement of large international financial institutions, both national and domestic. First, before the project is carried out, sufficient pre-project research is conducted to fully consider the risks that the project may face. Second, the government should reduce the time and cost of formalities for the implementation of infrastructure projects. Third, the government and large financial institutions provide financial guarantees and non-financial guarantees for the project, or undertake part of the construction costs through subsidies. Fourth, for risks from infrastructure users, the state can add a clause in the franchise law that imposes fines or other penalties on users who fail to pay fees as required.

\section{CONCLUSION}

How to better realize the maintenance and appreciation of pension funds has become a new focus in the social security field in various countries. From the perspective of future development trends, pension funds will inevitably involve more investment fields. Firstly, this paper illustrates the feasibility of the investment of China's pension fund on infrastructure from three aspects: the matching degree between pension funds and infrastructure investment, the pressure of China's pension fund revenue and expenditure, and the needs of infrastructure construction. Then it analyzes and summarizes the basis of international experience. At the same time, it made suggestions for the future practice of China.

[10] Australian Prudential Regulation Authority. Quarterly Superannuation Performance,issued 20 August 2015, http://www.apra.gov.au/

[11] Wang Dabo. Research on pension fund infrastructure investment : experience of OECD countries and investment choices of Chinese enterprise annuity. Financial Market,2012(4)47

[12] Newell, G.and Peng, The Performance of Unlisted Infrastructure in Investment Portfolios [J]. Journal of Property Research ,2011(1) 59-74.

[13] Russell Investment. Australians and Infrastructure Investments, 2012 ,available t:http://www.russell.com/AU/

pdfs/capital-markets-reserach/research/2012-March-Aus And Infra.pdf

\section{ACKNOWLEGEMENTS}

This paper has absorbed the thoughts of many previous research results, from which it has obtained many guidance and enlightenments. I should also thank all the classmates of the School of Public Administration, Yunnan University of Finance and Economics for their long term support and help offered to my study.

\section{REFERENCE}

[1] Georg Inderst, Pension Fund Investment in Infrastructure, at "OECD/IOPS Global Forum on Private Pension" on 30-31 Oct. 2008

[2] Asieh Mansou,Performance Characteristic of Infrastructure Investment, RREEF research report. 2007

[3] BBVA,Pension Funds an An Investor in Infrastructure Projects in Latin America,.2012,pp.17

[4] BBVA,Infrastructure Investment and Pension Funds in Chile, May 2011,pp.4-5

[5] Yuan Zhongmei,An International Comparison on Pension Funds' PPP Infrastructure Investment and Its Enlightenment, contemporary Economic Management[J],2016(9)79

[6] OECD. Infrastructure Financing Instruments and Incentives.2015. www.oecd.org/finance/lti.

[7] Tian TIanyuan.The Case Study of Pension Fund Investment in Infrastructure in Latin America and Its Enlightenment to Cina,2012,pp31-37

[8] BBVA Research. Factors that impact on pension fund investmentsin infrastructure under the current global financial regulation Im-plications of the New Regulatory[R/OL]. April 29/30 , 2015.https://www.bbvaresearch.com/en/publicaciones/factors -that -impact -on -pension-fund-investments-in-infrastructure/.

[9] Yuan Zhongmei, An International Comparison on Pension Funds' PPP Infrastructure Investment and Its Enlightenment, contemporary Economic Managemen[J]t,2016(9)79 